\title{
Noninvasive diagnostic tests for Helicobacter pylori infection in children
}

\author{
Sibylle Koletzko MD
}

\author{
S Koletzko. Noninvasive diagnostic tests for Helicobacter pylori \\ infection in children. Can J Gastroenterol 2005;19(7):433-439.
}

\author{
Diagnostic non effractif de l'infection à \\ Helicobacter pylori chez les enfants
}

\begin{abstract}
Noninvasive tests can be used for the initial diagnosis of Helicobacter pylori infection and to monitor the success of eradication therapy. In populations with a low prevalence of $H$ pylori infection (children living in North America and Europe), a high sensitivity is required to make the test valuable for clinical practice. The ${ }^{13} \mathrm{C}$-urea breath test has been validated in children of different age groups in a significant number of infected and noninfected children in several countries and, thus far, is the only noninvasive test that fulfills sensitivity and specificity quality standards. In studies to date, enzyme immunoassays using monoclonal antibodies to detect $H$ pylori antigen in stool provide excellent results, but the number of children tested, particularly posttreatment, is not sufficient to recommend the test. All other noninvasive stool tests or methods based on the detection of specific antibodies in serum, whole blood, urine or saliva have limited accuracy in comparison with the ${ }^{13} \mathrm{C}$-urea breath test. Therefore, these tests cannot be recommended for clinical decision making in pediatric patients.
\end{abstract}

Key Words: Antigen stool test; Children; Helicobacter pylori; Infants; Serology; Urea breath test

A wide variety of noninvasive diagnostic tests are available for the detection of Helicobacter pylori using whole blood, serum, saliva, urine, stool and expired air for analysis. All diagnostic tests applied in adults are generally feasible in children; however, tests requiring active collaboration are more difficult to perform in infants, toddlers or handicapped children (eg, if expired air or timed urine collections are required). Tests based on whole blood or serum cannot be regarded as noninvasive because blood sampling causes pain and induces anxiety, especially in young children. Blood sampling in healthy children, or repeated testing in diseased children, is not justified ethically if other noninvasive methods are available that provide the same information.

It is generally accepted that a diagnostic test should be validated in the population under investigation. This applies for geographical region, ethnicity or immigrant status and, particularly, for age. A crucial question for all tests performed in a pediatric population is whether the accuracy of the applied method is influenced by the age of the tested child. Different age groups need to be considered: infants, toddlers, preschool and school-age children, and adolescents (1). Reliable noninvasive tests which are feasible in young children are essential to study the transmission of $\mathrm{H}$ pylori because most individuals (in both industrialized and developing countries) become
Des tests non effractifs peuvent être utilisés pour poser un diagnostic d'infection à Helicobacter pylori et pour vérifier la réussite du traitement d'éradication. Chez les populations où la prévalence de l'infection à $H$ pylori est faible (enfants de l'Amérique du Nord et de l'Europe), il faut un fort degré de sensibilité pour que le test soit valable en pratique clinique. Le test respiratoire à l'urée marquée au ${ }^{13} \mathrm{C}$ a été validé chez des enfants de différents groupes d'âge et auprès d'un nombre significatif d'individus infectés et indemnes dans plusieurs pays et, à ce jour, il s'agit du seul test non effractif doté d'une sensibilité et d'une spécificité correspondant aux normes de qualité en vigueur. Dans les études menées à ce jour, les immunodosages enzymatiques avec anticorps monoclonaux pour le dépistage de l'antigène de $H$ pylori dans les selles donnent d'excellents résultats, mais le nombre d'enfants testés, particulièrement après le traitement n'est pas suffisant pour que l'on puisse recommander ce test. Tous les autres tests non effractifs sur des spécimens de selles et les méthodes basées sur le dépistage des anticorps spécifiques dans le sérum, le sang entier, l'urine ou la salive sont d'une précision limitée comparativement au test respiratoire à l'urée marquée au ${ }^{13} \mathrm{C}$. Par conséquent, on ne peut pas recommander leur utilisation dans le cadre d'un processus décisionnel clinique auprès de patients pédiatriques.

infected during the first few years of life $(2,3)$. Most of the validation studies in children included only a few infants and toddlers, particularly $H$ pylori-infected individuals. Only when increasing numbers of patients are tested and separated into subgroups by age does it become apparent that the accuracy of most tests are lower in young children if the same cut-off values established for older children or adults are used $(1,4,5)$.

Noninvasive tests need to be compared with a 'gold standard', but no single test for detection of $H$ pylori infection can be used as a fully reliable reference method. Therefore, concordant results of at least two biopsy-based tests are needed to define $H$ pylori status. Culture tests are considered to be $100 \%$ specific and, therefore, a positive culture is sufficient to prove $H$ pylori infection. If culture was not successful or performed, concordant positive results for both histology and the rapid urease test indicate $H$ pylori-positive status. To define $H$ pylorinegative status, all invasive tests performed have to provide negative results.

\section{UREA BREATH TESTS}

All of the different breath tests available for the detection of $H$ pylori infection use urea as a test substance. Urease is an essential enzyme for the survival of $H$ pylori. In noninfected individuals, urea leaves the stomach unchanged unless there is

Ludwig-Maximilians University, Munich, Germany

Correspondence: Dr Sibylle Koletzko, Dr von Haunersches Kinderspital, Ludwig-Maximilians University, Lindwurmstr 4, D-80337 Munich,

Germany. Telephone 49-89-5160-2811, fax 49-89-5160-7898, e-mail Sibylle.Koletzko@med.uni-muenchen.de 


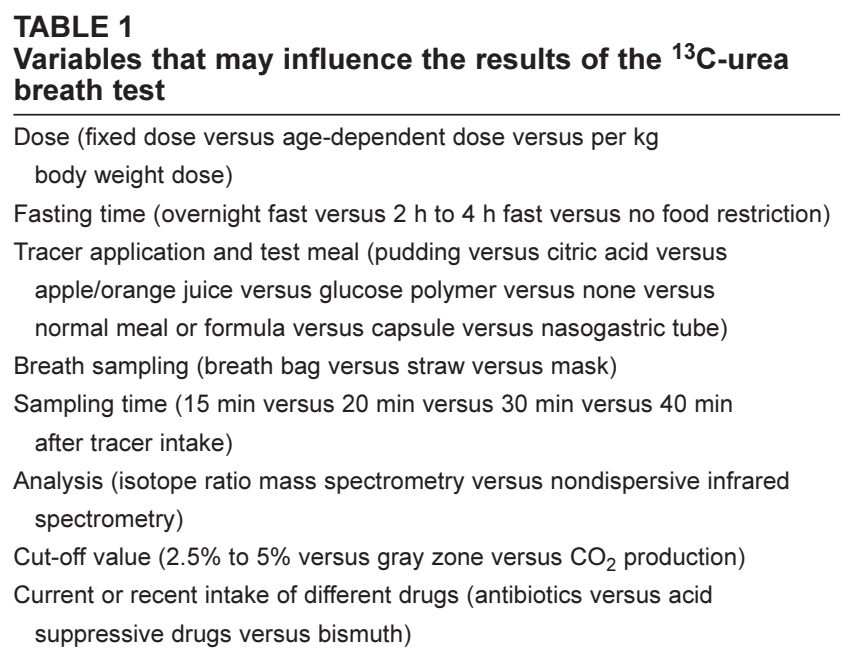

urease activity from other bacteria in the oral cavity, or in situations of gastric bacterial overgrowth. In the presence of $H$ pylori, or other urease-containing bacteria, urea is split into ammonia and $\mathrm{CO}_{2}$. The detection of the hydrolysis products is achieved by labelling urea with different stable isotopes: ${ }^{13} \mathrm{C}$ for detection of ${ }^{13} \mathrm{CO}_{2}$ in the expired air (6), and ${ }^{15} \mathrm{~N}$ for detection of ${ }^{15} \mathrm{~N}$-labelled ammonia in the urine (7). Stable isotopes are safe even in very young infants, and the tests can be repeated without risk to the child (8). However, these elegant tests tend to be expensive due to the costs of the labelled tracer and, particularly, the mass spectrometry or infrared spectroscopy equipment needed for analysis of the expired air $(8,9)$. Breath tests with ${ }^{14} \mathrm{C}$-urea are not acceptable in children because avoidable radiation is involved.

Thus far, the ${ }^{13} \mathrm{C}$-urea breath test (UBT) is the only test to be extensively validated in children in comparison with invasive methods. Results of the UBT are traditionally reported as delta over baseline (DOB) values of the measured ${ }^{13} \mathrm{CO}_{2}$ to ${ }^{12} \mathrm{CO}_{2}$ ratio. $\mathrm{DOB}$ values exceeding a fixed cut-off value are considered indicative of $\mathrm{H}$ pylori infection. A large variety of test protocols have been used with respect to variable tracer dose and application, test meal and sampling time, etc (Table 1). In spite of these large differences, the accuracy of the test in the different studies was excellent, indicating that the UBT provides good discrimination between positive and negative test results (Table 2). The UBT has also been validated in 161 children living in developing countries, with a sensitivity of $94 \%$ and a specificity of $99 \%$ (10).

However, gastric $\mathrm{pH}$, age, dose and application of tracer, and interfering drugs should be considered to achieve the best possible sensitivity and specificity.

\section{Gastric pH}

Gastric acidity is essential for urease activity. H pylori is not found in the absence of gastric acid secretion (ie, in many patients with atrophic gastritis [11]) because urea is toxic for this bacterium at a neutral $\mathrm{pH}$; the in vivo environment must be moderately acidic to allow colonization. It is well known that under normal conditions, $H$ pylori prevalence in antrum exceeds that in fundus (where the acidity is much higher); with proton pump inhibitor (PPI) treatment, the bacterial numbers decrease in the antrum and increase in the fundus (12). In vitro studies (13) have shown that urease activity is almost 40 -fold greater at $\mathrm{pH} 3.5$ compared with $\mathrm{pH}$ 7.4. In the fasting state, DOB values of infected children were higher, and the DOB value peak appeared earlier compared with testing in the postprandial phase (14). To obtain optimal test conditions, the test should be performed on an empty stomach (at least $4 \mathrm{~h}$ after last food intake) and the test meal should be an acidic fluid. In comparative trials in infected adults, it was demonstrated that citric acid $(4 \mathrm{~g} / 100 \mathrm{~mL})$ gave the highest DOB values, with an earlier rise in $\mathrm{DOB}$ values compared with lower concentrations of citric acid $(1 \mathrm{~g} / 100 \mathrm{~mL}$ or $2 \mathrm{~g} / 100 \mathrm{~mL})$, and with water or Ensure pudding (Abbott-Ross, USA) $(15,16)$. Citric acid acts with Ure1, a pH-sensitive urea channel of $\mathrm{H}$ pylori, and can counteract the DOB-reducing effect of bicarbonate or $\mathrm{H}_{2}$-receptor inhibitors (17). Because citric acid is not well accepted in children, apple or orange juice with a $\mathrm{pH}$ of approximately 3.4 seems to be a good alternative (5).

\section{Age, dose and application of tracer}

In infants and toddlers, false-positive results affect the accuracy of the test $(5,18)$. When the results of more than 3000 UBTs in children were analyzed (including large numbers of infants and toddlers), a significant inverse relationship between $D O B$ values and age in both infected and noninfected children was found (1). This inverse relationship resulted in a higher rate of falsepositive tests in infants and young children compared with school-age children and adolescents (5). ${ }^{13} \mathrm{C}$-enrichment in the expired air depends not only on the ${ }^{13} \mathrm{C}$-urea dose given and the amount of ${ }^{13} \mathrm{C}$-urea hydrolyzed by bacterial urease from $\mathrm{H}$ pylori and other urease-positive bacteria in the oral cavity, but also on the individual's $\mathrm{CO}_{2}$ production and the degree of ${ }^{13} \mathrm{CO}_{2}$ dilution within the body's $\mathrm{CO}_{2}$ and bicarbonate pools. $\mathrm{CO}_{2}$ production is known to be influenced by several relatively constant factors including age, sex, weight and height, but also by variable factors such as food intake and physical activity. There are several options to reduce the risk for false-positive results in young children. The mouth should be rinsed after tracer intake to avoid splitting of the urea by urease-producing oral flora (18). Also, reducing the dose in younger age groups from $75 \mathrm{mg}$ to $45 \mathrm{mg}$ results in an excellent specificity in children between two and 12 years of age (19). Adapting the cut-off would be another option; in children younger than two years of age, the cut-off should be no lower than $5 \%$. The age-dependence of the UBT can also be eliminated if results are normalized for the estimated individual $\mathrm{CO}_{2}$ production rate $(20,21)$.

\section{Interfering drugs}

Intake of antibiotics like penicillin or cephalosporins gave false-negative UBT results in approximately $25 \%$ to $30 \%$ of $H$ pylori-infected adults, even one week after stopping the drugs $(22,23)$. The test turned positive in all 10 patients tested after six weeks, indicating suppression but not clearance of the bacteria. Data in children are not available.

PPIs have a direct inhibitory effect on $\mathrm{H}$ pylori both in vivo and in vitro. As mentioned above, $\mathrm{H}$ pylori urease activity is much lower with increasing $\mathrm{pH}$. After only one to four weeks of a standard-dose PPI treatment, $20 \%$ to $30 \%$ of H pylori-positive adults have a false-negative UBT. The DOB value rises above the cut-off within two weeks after stopping PPI (24); in children, only anecdotal data exist and other acid suppressing drugs have less effect on the UBT. $\mathrm{H}_{2}$-receptor inhibitors decrease the DOB values of the UBT, which can be reversed by using citric acid solution as the test meal (17). However, neither 
TABLE 2

Validation studies for the ${ }^{13} \mathrm{C}$-urea breath test versus biopsy-based methods in children

\begin{tabular}{|c|c|c|c|c|c|c|c|c|c|}
\hline Country (reference) & $\begin{array}{l}\text { Subjects } \\
\text { (n) }\end{array}$ & $\begin{array}{c}\text { Patients } \\
<6 \text { years }(n)\end{array}$ & $\begin{array}{c}\mathrm{Hp}+ \\
\text { patients (n) }\end{array}$ & $\begin{array}{l}\text { Tracer } \\
\text { dose }\end{array}$ & Test meal & $\begin{array}{c}\text { Cut-off } \\
(\%)\end{array}$ & $\begin{array}{l}\text { Time } \\
\text { (min) }\end{array}$ & $\begin{array}{c}\text { Sensitivity } \\
(\%)^{*}\end{array}$ & $\begin{array}{c}\text { Specificity } \\
(\%)^{*}\end{array}$ \\
\hline France $(56)$ & 88 & - & 38 & $75 \mathrm{mg}$ & Citric acid & 3.4 & 40 & 100 & 98 \\
\hline Germany (5) & 149 & 53 & 66 & $75 \mathrm{mg}$ & Apple juice & 5.0 & 30 & 100 & 93 \\
\hline Germany (57) & 251 & - & 133 & $75 \mathrm{mg}$ & Roll with $50 \mathrm{~mL} \mathrm{H}_{2} \mathrm{O}$ & 5.3 & 30 & 99 & 93 \\
\hline European multicentre (19) & 316 & 48 & 133 & $45 / 75 \mathrm{mg}$ & Apple juice, orange juice & 4.0 & 30 & 96 & 97 \\
\hline
\end{tabular}

${ }^{*}$ Despite different test protocols for tracer dose, test meal, cut-off for delta over baseline value and time of breath sampling after tracer intake, the results were excellent (sensitivity and specificity $>90 \%$, with most $>95 \%$ ). Hp+ Helicobacter pylori-positive

TABLE 3

Validation studies of the polyclonal antibody enzyme immunoassay stool test (Premier Platinum HpSA, Meridian Diagnostics, Italy) versus biopsy-based methods in children before therapy

\begin{tabular}{|c|c|c|c|c|c|c|}
\hline Country (reference) & Subjects (n) & Hp+ patients (n) & Age range (years) & Reference test & Sensitivity (\%) & Specificity (\%) \\
\hline Italy (29) & 198 & 52 & 1 to 18 & RUT, histology & 100 & 93 \\
\hline Taiwan (59) & 53 & 27 & 10 to 14 & RUT, histology, culture & 89 & 93 \\
\hline France $(60)$ & 58 & 23 & 6 to 17 & Histology, culture & 87 & 97 \\
\hline Germany (30) & 145 & 45 & 0.5 to 19 & RUT, histology, culture & 89 & 94 \\
\hline Netherlands (27) & 106 & 30 & 1 to 18 & Histology, culture & 100 & 92 \\
\hline Italy (26) & 85 & 22 & 2 to 17 & Biopsy & 100 & 70 \\
\hline Poland (61) & 107 & 62 & 8 to 14 & RUT, culture & 89 & 95 \\
\hline Europe multicentre (19) & 316 & 133 & 2 to 17 & RUT, histology, culture & 92 & 73 \\
\hline Italy (62) & 174 & 174 & 2 to 17 & Biopsy & 91 & 87 \\
\hline United States (63) & 121 & 9 & 0.5 to 17 & RUT, histology & 67 & 99 \\
\hline Brazil (10) & 107 & 32 & 1 to 18 & RUT, histology, culture & 94 & 99 \\
\hline
\end{tabular}

Hp+ Helicobacter pylori-positive; RUT Rapid urease test

$\mathrm{H}_{2}$-receptor inhibitors nor antacids affect the sensitivity of the test results in adults (23). No data exist for children.

Conclusions regarding the UBT

- In spite of different test modifications, the UBT has an excellent performance with good separation between negative and positive test results in children both before and after treatment.

- Antibiotics should be stopped at least four weeks before testing.

- Treatment with a PPI must be stopped at least two weeks before testing.

- $\mathrm{H}_{2}$-receptor antagonists and antacids should be stopped two days before testing (it is preferable to use a citric acid solution as the test meal).

- Perform the UBT on an empty stomach (eg, $4 \mathrm{~h}$ or greater postprandially) to ensure a high gastric acidity.

- Use an acid solution as the test meal (citric acid is ideal, or orange or apple juice), with a mouth rinse after tracer intake.

- An inverse relationship between age and DOB values exists if a fixed tracer dose (eg, $75 \mathrm{mg}$ ) is given.

- False-positive results occur more often in infants and young children, particularly sick infants. Specificity can be improved by adjusting for the $\mathrm{CO}_{2}$ production rate. Alternative options are lowering the tracer dose or increasing the cut-off value.

\section{STOOL TESTS}

Detection of $H$ pylori antigen in stool is another attractive noninvasive method that seems very suitable for both clinical use and epidemiological studies. The most common method of antigen detection in stool is an enzyme immunoassay (EIA). Stool tests are obviously more convenient than the UBT in pediatric patients. Stool samples can be obtained from children without their active collaboration and are easily transportable by mail. Neither keeping the samples at room temperature for up to five days nor freezing for months or even years seems to influence the accuracy of stool tests (25-28). In most countries, an EIA would be less costly than the UBT. EIAs can be based either on polyclonal or, more recently, on monoclonal antibodies.

\section{Polyclonal antibody EIA}

The first commercial EIA tests to detect $H$ pylori antigen in stool was the Premier Platinum HpSA (Meridian Diagnostics, Italy), a test based on polyclonal antibodies. The first results were quite promising for pretreatment $(27,29,30)$ and posttreatment testing (31) in children; however, testing the same stool samples with different production lots of the polyclonal antibody indicated interassay variation (32). This may explain the wider range reported for the sensitivity and specificity of the polyclonal stool test (Tables 3, 4 and 5).

\section{Monoclonal antibody EIA}

The development of a stool test based on monoclonal antibodies (FemtoLab H pylori Cnx, Connex, Germany) seems to avoid the problem of intertest variability. The test was validated against invasive methods in a multicentre study (25) including 
TABLE 4

Validation studies of the polyclonal antibody enzyme immunoassay stool test (Premier Platinum HpSA, Meridian Diagnostics, Italy) before therapy versus the ${ }^{13} \mathrm{C}$-urea breath test (UBT) in children

\begin{tabular}{lcccccc}
\hline Country (reference) & Subjects $(\mathbf{n})$ & Hp+ patients $(\mathbf{n})$ & Age range (years) & Reference test & Sensitivity (\%) & Specificity (\%) \\
\hline Japan multicentre (64) & 264 & 76 & 2 to 17 & UBT & 96 & 97 \\
Germany (65) & 162 & 24 & 0.7 to 15 & UBT & 92 & 99 \\
Germany (66) & 69 & 26 & 3 to 5 & UBT & 85 \\
Germany (30) & 129 & 3 & 0.9 to 3 & UBT & 67 & 98 \\
Austria (32,67) & 78 & 49 & 3 to 15 & UBT & 93 & 99 \\
United Kingdom (68) & 119 & 26 & 3 to 18 & UBT & 88 \\
\hline
\end{tabular}

$\mathrm{Hp}+$ Helicobacter pylori-positive

TABLE 5

Validation studies of the polyclonal antibody enzyme immunoassay stool test (Premier Platinum HpSA, Meridian Diagnostics, Italy) four to eight weeks post-therapy versus the ${ }^{13} \mathrm{C}$-urea breath test (UBT) or biopsy-based methods in children

\begin{tabular}{|c|c|c|c|c|c|c|}
\hline Country (reference) & Subjects (n) & Hp+ patients (n) & Age range (years) & Reference test & ensitivity (\%) & Specificity (\%) \\
\hline Japan (64) & 21 & 2 & 2 to 17 & UBT & 100 & 100 \\
\hline Germany (30) & 22 & 3 & 5 to 16 & UBT & 100 & 100 \\
\hline Italy (31) & 60 & 11 & 1 to 15 & UBT & 100 & 94 \\
\hline United Kingdom (68) & 119 & 26 & 3 to 18 & UBT & 88 & 82 \\
\hline European multicentre (19) & 109 & 22 & 3 to 17 & UBT & 67 & 93 \\
\hline France $(60)$ & 11 & 3 & 6 to 17 & Biopsy: histology and culture & 67 & 100 \\
\hline
\end{tabular}

*The same stool samples were measured twice with different lots of the test resulting in discrepant results. Hp+ Helicobacter pylori positive

TABLE 6

Validation studies of the monocolonal antibody enzyme immunoassay stool test compared with the ${ }^{13} \mathrm{C}$-urea breath test (UBT) or biopsy-based methods in children and adults before therapy

\begin{tabular}{|c|c|c|c|c|c|c|}
\hline Country (reference) & Subjects (n) & Hp+ patients (n) & Age range (years) & Reference test & Sensitivity (\%) & Specificity (\%) \\
\hline Austria (32) & 82 & 39 & 0.5 to 18 & UBT & 98 & 97 \\
\hline Germany, France and Netherlands (25) & 302 & 92 & 0.5 to 18 & RUT, histology, culture & 98 & 99 \\
\hline Germany (69) & 59 & 26 & Adults & UBT & 94 & 89 \\
\hline Norway (40) & 122 & 54 & Adults & Histology, culture & 98 & 94 \\
\hline Germany (70) & 50 & 50 & Adults & RUT, histology, UBT & 94 & - \\
\hline Spain (35) & 34 & 34 & Adults & UBT & 94 & - \\
\hline Italy (34) & 187 & 58 & Adults & UBT & 90 & 96 \\
\hline
\end{tabular}

Hp+ Helicobacter pylori-positive; RUT Rapid urease test

TABLE 7

Validation studies of the monocolonal antibody enzyme immunoassay stool test compared with the ${ }^{13} \mathrm{C}$-urea breath test (UBT) or biopsy-based methods in children and adults after therapy

\begin{tabular}{|c|c|c|c|c|c|c|}
\hline Country (reference) & Subjects (n) & Hp+ patients (n) & Age range (years) & Reference test & Sensitivity (\%) & Specificity (\%) \\
\hline Austria (32) & 39 & 8 & 3 to 15 & UBT & 100 & 100 \\
\hline Germany (70) & 119 & 26 & Adults & UBT & 100 & 100 \\
\hline Germany (33) & 148 & 35 & Adults & UBT & 94 & 94 \\
\hline
\end{tabular}

$\mathrm{Hp}+$ Helicobacter pylori-positive

302 children, 92 of whom were infected by H pylori. The test misclassified only four of 302 children (two false-positive and two false-negative results) giving a sensitivity of $98 \%$ and a specificity of $99 \%$. The reliability of the monoclonal EIA was confirmed in further studies, both in children and adults pre- (Table 6) and post-treatment (Table 7). However, the number of published studies in children, particularly in the post-treatment setting, is too small to give final recommendations. When the monoclonal antibody EIA was directly compared with the polyclonal antibody EIA on the same stool samples, the performance was always in favour of the monoclonal test, with a higher accuracy and better separation between positive and negative test results (33-35).
There was concern that the accuracy of the test may suffer if performed in nonspecialized laboratories; however, this concern also applies for the UBT, where several mistakes can occur during tracer application and air sampling, etc, if untrained personnel perform the test on children.

Immunochromatographic quick test

The newest development is an immunochromatographic quick test with monoclonal antibodies (Immunocard STAT! HpSA, Meridian Bioscience, Italy) (36). This one-step test is convenient to perform in every office, with results available within $10 \mathrm{~min}$. The interobserver agreement is good, but equivocal results occur 
in approximately $5 \%$ of stool samples. The accuracy of the rapid stool test is comparable before and six to eight weeks after therapy $(37,38)$. According to limited published results from Germany, Spain and Taiwan (35), the office-based test is less reliable than the monoclonal antibody EIA or the UBT. However, in settings where neither the UBT nor the monoclonal antibody EIA are available, feasible or affordable, the immunochromatographic test may become a noninvasive alternative to assess the H pylori status pre- or post-treatment in children.

\section{Polymerase chain reaction-based methods}

Detection of bacterial DNA in stool by the polymerase chain reaction (PCR) shows promising accuracy in adults and children. Makristathis et al (32) performed PCR on the stools of 49 children (mean age 11.1 years) with concordant positive results of UBT and serology (32). They reported a pretreatment sensitivity of $91.8 \%$ (45 of 49 children). Four weeks after eradication therapy, all eight children with a positive UBT were still positive by stool PCR. However, false-positive results were common four to eight weeks after therapy. Specificity improved with an increasing time interval after therapy, ranging from $68.8 \%$ after four weeks to $87.5 \%$ after eight weeks. The same group from Vienna (39) developed a novel biprobe real-time PCR assay, followed by hybridization melting point analysis to detect point mutations in the $23 \mathrm{~S}$ ribosomal RNA gene which are associated with resistance to clarithromycin. For detection of $\mathrm{H}$ pylori in stool, sensitivity and specificity were high (both 98\%). The real-time PCR method was able to detect seven of 11 patients harbouring a clarithromycinresistant mutant. This assay is the first method to noninvasively provide information on macrolide resistance, which is increasingly important due to the rising rate of clarithromycin resistance in H pylori strains from pediatric patients (40).

\section{Age}

To date, the studies performed in children show that the performance characteristics of the test are independent of age. In addition, there was no relationship between the optical density and age, either in $H$ pylori-infected or -noninfected children $(25,30)$. When the polyclonal test was applied to 129 healthy infants and toddlers between 0.9 and 3.1 years of age, the concordance between the results of the UBT and stool test was $96 \%$ (124 of 129 children). The stool test misclassified two children (one false-positive and one false-negative) and the UBT misclassified the remaining three children (all false-positive results).

\section{Acute bleeding}

Gisbert et al (35) investigated the reliability of three different tests to assess $H$ pylori status in 34 adults with acute bleeding from peptic ulcer. The best sensitivity was obtained with the monoclonal antibody EIA (94\%), while the polyclonal antibody EIA detected $74 \%$ and the rapid urease test detected only $60 \%$ of infected patients.

\section{Acid suppressing drugs}

In many patients, it is not possible to stop acid suppressive therapy before investigation of $H$ pylori infection. As pointed out above, the UBT may give false-negative results in patients taking PPIs $(23,24)$. Gatta et al (23) and Laine et al (24) compared the influence of treatment with PPI and antacids on UBT and polyclonal antibody EIA stool test results. While PPIs decreased the sensitivity of both methods, antacids did not. Only one study (41) investigated the effect of PPIs on the monoclonal antibody stool test. Immediately following two to four weeks of PPI treatment, the stool test remained positive in all $43 \mathrm{H}$ pylori-infected patients tested. However, after stopping the PPI for seven days, the test became negative in two of 39 patients. No studies are available in pediatric patients.

\section{Conclusions regarding stool antigen tests}

- The stool tests for detection of H pylori antigen are easy to perform, independent of age, do not require a visit of the patient to the office and are cheaper compared with the UBT.

- The polyclonal antibody EIA seemed to have a high production lot variability and, therefore, this test was less reliable than the UBT or invasive methods.

- The office-based immunochromatographic test was less accurate than the UBT, with approximately 5\% equivocal readings.

- The monoclonal antibody EIA can be regarded as equally reliable compared with the UBT, and more reliable than the other two stool tests investigated thus far; however, the number of published studies in children is still limited.

- In settings where the breath test was not available for children, the monoclonal antibody EIA stool test seemed to be an excellent noninvasive alternative to assess the $\mathrm{H}$ pylori status before and/or after treatment.

\section{SERUM AND BLOOD TESTS}

$H$ pylori infection induces a cellular and humoral immune response in the host, resulting in an early increase of specific immunoglobin $(\mathrm{Ig}) \mathrm{M}$, and a later and persistent increase of specific IgA and IgG antibodies. These antibodies can be detected in whole blood, serum, urine and saliva. Antibody titres can remain positive for months despite resolution of the infection (42). Therefore, tests based on determination of specific antibodies were not reliable to verify eradication of $H$ pylori.

Many serological tests are commercially available; they are easy to perform, inexpensive and, therefore, widely in use. Despite these advantages, they have not been recommended for clinical practice in pediatric patients, either by the previous Canadian consensus statement or by the American or European consensus statement (43-45).

The main concerns are age dependence, particularly with respect to sensitivity and test-to-test variability. IgA-based tests detect only $20 \%$ to $50 \%$ of $\mathrm{H}$ pylori-infected children, and are not suitable for diagnosis (46-48). IgG-based tests offer a better sensitivity than IgA-based tests, but the sensitivity of most tests is much lower when used in children compared with adults of the same geographical region. The use of cut-off values obtained in validation studies in adults results in a failure to detect a large proportion of infected children, especially in children younger than six to eight years of age. Oliveira et al (4) used a secondgeneration EIA in comparison with biopsy-based methods and found a low sensitivity of $44 \%$ in children aged two to six years. Sensitivity increased to $77 \%$ in children aged seven to 11 years, and to $93 \%$ in adolescents, which is comparable with results in adults. When two IgG-based EIAs were applied to the sera of 175 children with biopsy-proven H pylori status, a remarkable difference of sensitivity was observed, mainly in the younger 
age groups (46). Immunoblotting was found to be superior to serology for diagnosing $H$ pylori infection in children (49). More recent third-generation EIAs seem to perform better, but sensitivity is still lower compared with the UBT (19). Tests based on the detection of $\mathrm{H}$ pylori antibodies in saliva or office-based tests on whole blood or serum display even worse performance characteristics than laboratory-based serological EIAs $(50,51)$. Therefore, these tests cannot be recommended in children of any age group, either for clinical use or for epidemiological studies.

\section{URINE AND SALIVARY TESTS}

In children, the detection of specific antibodies against $H$ pylori in urine is even less reliable than the serological tests. While a study (52) in adults using a rapid office-based urine assay showed a sensitivity of $94 \%$, the same test recognized only $30 \%$ of $\mathrm{H}$ pylori-infected children in a large European multicentre trial (19). A laboratory-based urinary EIA in the patients performed better, but a sensitivity of $63 \%$ is still unacceptable.

A similar low sensitivity applies to the detection of specific antibodies in the saliva of children (53). The sensitivity was only $33 \%$ in children below four years of age, but increased to
$81 \%$ in school-age children. Similar results were obtained in other pediatric studies $(51,54)$ showing a low sensitivity with a good specificity. Although these tests are noninvasive, the accuracy is unacceptable in the presence of better alternatives.

The ${ }^{15} \mathrm{~N}$-urea test is hampered by the fact that a timed urine collection is necessary, which makes the test unsuitable in younger and handicapped children who have difficulty voiding on demand. Even in school-age children, the reported sensitivity and specificity of the urine test were inferior to that of the UBT (7).

\section{CONCLUSIONS}

Our knowledge has increased remarkably regarding noninvasive testing for $\mathrm{H}$ pylori infection in children. Thus far, only the UBT is established to diagnose or exclude $H$ pylori infection or - clinically more important - to monitor the effect of therapy in pediatric patients. The monoclonal antibody EIA to detect $H$ pylori antigen in stool is very promising. If further studies confirm the published results, this could be a good alternative if the UBT is not available or too expensive. All other tests display poor sensitivity and cannot be recommended in pediatric populations of industrialized countries with a low prevalence of the disease.

\section{REFERENCES}

1. Koletzko S, Feydt-Schmidt A. Infants differ from teenagers: Use of non-invasive tests for detection of Helicobacter pylori infection in children. Eur J Gastroenterol Hepatol 2001;13:1047-52.

2. Perez-Perez GI, Rothenbacher D, Brenner H. Epidemiology of Helicobacter pylori infection. Helicobacter 2004;9(Suppl 1):1-6.

3. Sinha SK, Martin B, Sargent M, McConnell JP, Bernstein CN. Age at acquisition of Helicobacter pylori in a pediatric Canadian First Nations population. Helicobacter 2002;7:76-85.

4. Oliveira AMR, Rocha GA, Queiroz DM, et al. Evaluation of enzyme-linked immunosorbent assay for the diagnosis of Helicobacter pylori infection in children from different age groups with and without duodenal ulcer. J Pediatr Gastroenterol Nutr 1999;28:157-61.

5. Kindermann A, Demmelmair H, Koletzko B, Krauss-Etschmann S, Wiebecke B, Koletzko S. Influence of age on ${ }^{13} \mathrm{C}$-urea breath test results in children. J Pediatr Gastroenterol Nutr 2000;30:85-91. (Erratum in 2000;30:354).

6. Graham DY, Klein PD, Evans DJ Jr, et al. Campylobacter pylori detected noninvasively by the ${ }^{13} \mathrm{C}$-urea breath test. Lancet 1987;1:1174-7.

7. Krumbiegel P, Herbarth O, Kiess W, Müller DM, Richter T. Diagnosis of Helicobacter pylori infection in children: Is the ${ }^{15} \mathrm{~N}$ urine test more reliable than the ${ }^{13} \mathrm{C}$ breath test? Scand J Gastroenterol 2000;35:353-8.

8. Koletzko B, Demmelmair H, Hartl W, et al. The use of stable isotope technique for nutritional and metabolic research in paediatrics. Early Hum Dev 1998;53(Suppl):S77-97.

9. Koletzko S, Haisch M, Seeboth I, et al. Isotope-selective nondispersive infrared spectrometry for detection of Helicobacter pylori infection with ${ }^{13}$ C-urea breath test. Lancet 1995;345:961-2.

10. Carvalho-Costa-Cardinali L, Rocha GA, Rocha AM, et al. Evaluation of $\left[{ }^{13} \mathrm{C}\right]$ urea breath test and Helicobacter pylori stool antigen test for diagnosis of $\mathrm{H}$ pylori infection in children from a developing country. J Clin Microbiol 2003;41:3334-5.

11. Kuipers EJ, Appelmelk BJ. Helicobacter pylori and atrophic gastritis. Biomed Pharmacother 1997;51:150-5.

12. Kuipers EJ, Uyterlinde AM, Pena AS, et al. Increase of Helicobacter pylori-associated corpus gastritis during acid suppressive therapy: Implications for long-term safety. Am J Gastroenterol 1995;90:1401-6.

13. Rektorschek M, Weeks D, Sachs G, Melchers K. Influence of pH on metabolism and urease activity of Helicobacter pylori. Gastroenterology 1998;115:628-41.

14. Rowland M, Lambert I, Gormally S, et al. Carbon 13-labeled urea breath test for the diagnosis of Helicobacter pylori infection in children. J Pediatr 1997;131:815-20.

15. Graham DY, Runke D, Anderson SY, Malaty HM, Klein PD. Citric acid as the test meal for the ${ }^{13} \mathrm{C}$-urea breath test. Am J Gastroenterol 1999;94:1214-7.

16. Dominguez-Munoz JE, Leodolter A, Sauerbruch T, Malfertheiner P. A citric acid solution is an optimal test drink in the ${ }^{13} \mathrm{C}$-urea breath test for the diagnosis of Helicobacter pylori infection. Gut 1997;40:459-62.

17. Graham DY, Opekun AR, Jogi M, et al. False negative urea breath tests with $\mathrm{H}_{2}$-receptor antagonists: Interactions between Helicobacter pylori density and pH. Helicobacter 2004;9:17-27.

18. Imrie C, Rowland M, Bourke B, Drumm B. Limitations to carbon 13-labeled urea breath testing for Helicobacter pylori in infants. J Pediatr 2001;139:734-7.

19. Megraud F. Non-invasive tests to detect Helicobacter pylori infection in children and adolescents: Results of a multicentric European study. J Pediatr 2005. (In press)

20. Sauerwald T, Demmelmair H, Tasch C, Konstantopoulos N, Weigand H, Koletzko S. Improving accuracy of the ${ }^{13} \mathrm{C}$-urea breath test in children by normalizing results for $\mathrm{CO}_{2}$-production-rates. Gut 2000;47(Suppl 1):A93. (Abst)

21. Klein PD, Malaty HM, Czinn SJ, Emmons SC, Martin RF, Graham DY. Normalizing results of ${ }^{13} \mathrm{C}$-urea breath testing for $\mathrm{CO}_{2}$ production rates in children. J Pediatr Gastroenterol Nutr 1999;29:297-301.

22. Leung WK, Hung LC, Kwok CK, Leong RW, Ng DK, Sung JJ. Follow up of serial urea breath test results in patients after consumption of antibiotics for non-gastric infections. World J Gastroenterol 2002;8:703-6.

23. Gatta L, Vakil N, Ricci C, et al. Effect of proton pump inhibitors and antacid therapy on ${ }^{13} \mathrm{C}$ urea breath tests and stool test for Helicobacter pylori infection. Am J Gastroenterol 2004;99:823-9.

24. Laine L, Estrada R, Trujillo M, Knigge K, Fennerty MB. Effect of proton-pump inhibitor therapy on diagnostic testing for Helicobacter pylori. Ann Intern Med 1998;129:547-50.

25. Koletzko S, Konstantopoulos N, Bosman D, et al. Evaluation of a novel monoclonal enzyme immunoassay for detection of Helicobacter pylori antigen in stool from children. Gut 2003;52:804-6.

26. Roggero P, Bonfiglio A, Luzzani S, et al. Helicobacter pylori stool antigen test: A method to confirm eradication in children. J Pediatr 2002;140:775-7.

27. van Doorn OJ, Bosman DK, van't Hoff BW, Taminiau JA, ten Kate FJ, van der Ende A. Helicobacter pylori stool antigen test: A reliable non-invasive test for the diagnosis of Helicobacter pylori infection in children. Eur J Gastroenterol Hepatol 2001;13:1061-5.

28. Yee YK, Yip KT, Que TL, et al. Efficacy of enzyme immunoassay for the detection of Helicobacter pylori antigens in frozen stool specimens: Local validation. Aliment Pharmacol Ther 2002;16:1739-42.

29. Oderda G, Rapa A, Ronchi B, et al. Detection of Helicobacter pylori in stool specimens by non-invasive antigen enzyme immunoassay in children: Multicentre Italian study. BMJ 2000;320:347-8. 
30. Konstantopoulos N, Russmann H, Tasch C, et al. Evaluation of the Helicobacter pylori stool antigen test $(\mathrm{HpSA})$ for detection of Helicobacter pylori infection in children. Am J Gastroenterol 2001;96:677-83.

31. Oderda G, Rapa A, Marinello D, Ronchi B, Zavallone A. Usefulness of Helicobacter pylori stool antigen test to monitor response to eradication treatment in children. Aliment Pharmacol Ther 2001;15:203-6.

32. Makristathis A, Barousch W, Pasching E, et al. Two enzyme immunoassays and PCR for detection of Helicobacter pylori in stool specimens from pediatric patients before and after eradication therapy. J Clin Microbiol 2000;38:3710-4.

33. Leodolter A, Peitz U, Ebert MP, Agha-Amiri K, Malfertheiner P. Comparison of two enzyme immuno-assays for the assessment of Helicobacter pylori status in stool specimens after eradication therapy. Am J Gastroenterol 2002;97:1682-6.

34. Zambon CF, Basso D, Navaglia F, et al. Non-invasive diagnosis of Helicobacter pylori infection: Simplified ${ }^{13} \mathrm{C}$-urea breath test, stool antigen testing, or DNA PCR in human feces in a clinical laboratory setting? Clin Biochem 2004;37:261-7.

35. Gisbert JP, Trapero M, Calvet X, et al. Evaluation of three different tests for the detection of stool antigens to diagnose Helicobacter pylori infection in patients with upper gastrointestinal bleeding. Aliment Pharmacol Ther 2004;19:923-9.

36. Antos D, Crone J, Konstantopoulos N, Koletzko S. Evaluation of a novel rapid one-step immunochromatographic assay for detection of monoclonal Helicobacter pylori antigen in stool samples from children. J Clin Microbiol 2005;43:2598-601.

37. Leodolter A, Wolle K, Peitz U, Schaffranke A, Wex T, Malfertheiner P. Evaluation of a near patient fecal antigen test for the assessment of Helicobacter pylori status. Diagn Microbiol Infect Dis 2004:48:145-7.

38. Wu IC, Ke HL, Lo YC, et al. Evaluation of a newly developed office-based stool test for detecting Helicobacter pylori: An extensive pilot study. Hepatogastroenterology 2003;50:1761-5.

39. Schabereiter-Gurtner C, Hirschl AM, Dragosics B, et al. Novel real-time PCR assay for detection of Helicobacter pylori infection and simultaneous clarithromycin susceptibility testing of stool and biopsy specimens. J Clin Microbiol 2004:42:4512-8.

40. Crone J, Granditsch G, Huber WD, et al. Helicobacter pylori in children and adolescents: Increase of primary clarithromycin resistance, 1997-2000. J Pediatr Gastroenterol Nutr 2003;36:368-71.

41. Asfeldt AM, Lochen ML, Straume B, et al. Accuracy of a monoclonal antibody-based stool antigen test in the diagnosis of Helicobacter pylori infection. Scand J Gastroenterol 2004;39:1073-7.

42. Cutler AF, Prasad VM, Santogade P. Four-year trends in Helicobacter pylori IgG serology following successful eradication. Am J Med 1998;105:18-20.

43. Drumm B, Koletzko S, Oderda G. Helicobacter pylori infection in children: A consensus statement. J Pediatr Gastroenterol Nutr 2000;30:207-13.

44. Gold B, Colletti RB, Abbott M, et al; North American Society for Pediatric Gastroenterology and Nutrition. Helicobacter pylori infection in children: Recommendations for diagnosis and treatment. J Pediatr Gastroenterol Nutr 2000;31:490-7.

45. Sherman P, Hassall E, Hunt RH, Fallone CA, Veldhuyzen Van Zanten S, Thomson AB. Canadian Helicobacter Study Group Consensus Conference on the Approach to Helicobacter pylori Infection in Children and Adolescents. Can J Gastroenterol 1999;13:553-9.

46. Kindermann A, Tasch C, Sauerwald T, et al. Major differences of commercial ELISA to detect $H$ pylori infection in children. J Pediatr Gastroenterol Nutr 2000;31(Suppl 2):S148.

47. Khanna B, Cutler A, Israel NR, et al. Use caution with serologic testing for Helicobacter pylori infection in children. J Infect Dis 1998;178:460-5.

48. Czinn SJ. Serodiagnosis of Helicobacter pylori in pediatric patients. J Pediatr Gastroenterol Nutr 1999;28:132-4.

49. Raymond J, Sauvestre C, Kalach N, Bergeret M, Dupont C. Immunoblotting and serology for diagnosis of Helicobacter pylori infection in children. Pediatr Infect Dis J 2000;19:118-21.

50. Kindermann A, Faus-Kessler T, Ballauff A, et al. Evaluation of a rapid whole blood test to detect Helicobacter pylori infection in children. Scand J Gastroenterol 2001;36:572-6.

51. Luzza F, Oderda G, Maletta M, et al. Salivary immunoglobulin G assay to diagnose Helicobacter pylori infection in children. J Clin Microbiol 1997;35:3358-60.

52. Wu DC, Kuo CH, Lu CY, et al. Evaluation of an office-based urine test for detecting Helicobacter pylori: A prospective pilot study. Hepatogastroenterology 2001;48:614-7.

53. Gilger MA, Tolia V, Johnson A, et al. The use of an oral fluid immunoglobulin G ELISA for the detection of Helicobacter pylori infection in children. Helicobacter 2002;7:105-10.

54. Bode G, Marchildon P, Peacock J, Brenner H, Rothenbacher D. Diagnosis of Helicobacter pylori infection in children: Comparison of a salivary immunoglobulin $\mathrm{G}$ antibody test with the $\left(\left[{ }^{13}\right] \mathrm{C}\right)$ urea breath test. Clin Diagn Lab Immunol 2002;9:493-5.

55. Cadranel S, Corvaglia L, Bontems P, et al. Detection of Helicobacter pylori infection in children with standardized and simplified ${ }^{13} \mathrm{C}$-urea breath test. J Pediatr Gastroenterol Nutr 1998;27:275-80.

56. Kalach N, Briet F, Raymond J, et al. The ${ }^{13} \mathrm{C}$-carbon urea breath test for the noninvasive detection of Helicobacter pylori in children: Comparison with culture and determination of minimum analysis requirements. J Pediatr Gastroenterol Nutr 1998;26:291-6.

57. Herold R, Becker M. ${ }^{13}$ C-urea breath test threshold calculation and evaluation for the detection of Helicobacter pylori infection in children. BMC Gastroenterol 2002;2:12.

58. Kato S, Ozawa K, Konno M, et al. Diagnostic accuracy of the ${ }^{13} \mathrm{C}$-urea breath test for childhood Helicobacter pylori infection: A multicenter Japanese study. Am J Gastroenterol 2002;97:1668-73.

59. Ni YH, Lin JT, Huang SF, Yang JC, Chang MH. Accurate diagnosis of Helicobacter pylori infection by stool antigen test and 6 other currently available tests in children. J Pediatr 2000;136:823-7.

60. Husson MO, Rolland C, Gottrand F, et al. Evaluation of a Helicobacter pylori stool antigen test for the diagnosis and follow-up of infections in children. Eur J Clin Microbiol Infect Dis 2000;19:787-9.

61. Gosciniak G, Przondo-Mordarska A, Iwanczak B, Blitek A. Helicobacter pylori antigens in stool specimens of gastritis children before and after treatment. J Pediatr Gastroenterol Nutr 2003;36:376-80.

62. Bonamico M, Strappini PM, Bonci E, et al. Evaluation of stool antigen test, PCR on ORAL samples and serology for the noninvasive detection of Helicobacter pylori infection in children. Helicobacter 2004;9:69-76.

63. Elitsur Y, Lawrence Z, Hill I. Stool antigen test for diagnosis of Helicobacter pylori infection in children with symptomatic disease: A prospective study. J Pediatr Gastroenterol Nutr 2004;39:64-7.

64. Kato S, Ozawa K, Okuda M, et al. Accuracy of the stool antigen test for the diagnosis of childhood Helicobacter pylori infection: A multicenter Japanese study. Am J Gastroenterol 2003;98:296-300.

65. Braden B, Posselt HG, Ahrens P, Kitz R, Dietrich CF, Caspary WF. New immunoassay in stool provides an accurate noninvasive diagnostic method for Helicobacter pylori screening in children. Pediatrics 2000;106:115-7.

66. Rothenbacher D, Bode G, Brenner H. Diagnosis of Helicobacter pylori infection with a novel stool antigen-based assay in children. Pediatr Infect Dis J 2000;19:364-6.

67. Makristathis A, Pasching E, Schutze K, Wimmer M, Rotter ML, Hirschl AM. Detection of Helicobacter pylori in stool specimens by PCR and antigen enzyme immunoassay. J Clin Microbiol 1998;36:2772-4.

68. Shepherd AJ, Williams CL, Doherty CP, et al. Comparison of an enzyme immunoassay for the detection of Helicobacter pylori antigens in the faeces with the urea breath test. Arch Dis Child 2000;83:268-70.

69. Agha-Amiri K, Peitz U, Mainz D, Kahl S, Leodolter A, Malfertheiner P. A novel immunoassay based on monoclonal antibodies for the detection of Helicobacter pylori antigens in human stool. Z Gastroenterol 2001;39:555-60.

70. Weingart V, Russmann H, Koletzko S, Weingart J, Hochter W, Sackmann M. Sensitivity of a novel stool antigen test for detection of Helicobacter pylori in adult outpatients before and after eradication therapy. J Clin Microbiol 2004;42:1319-21. 


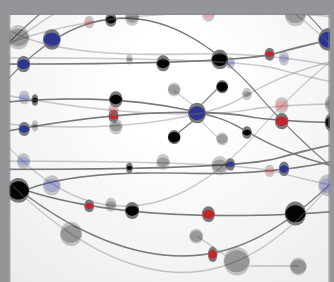

The Scientific World Journal
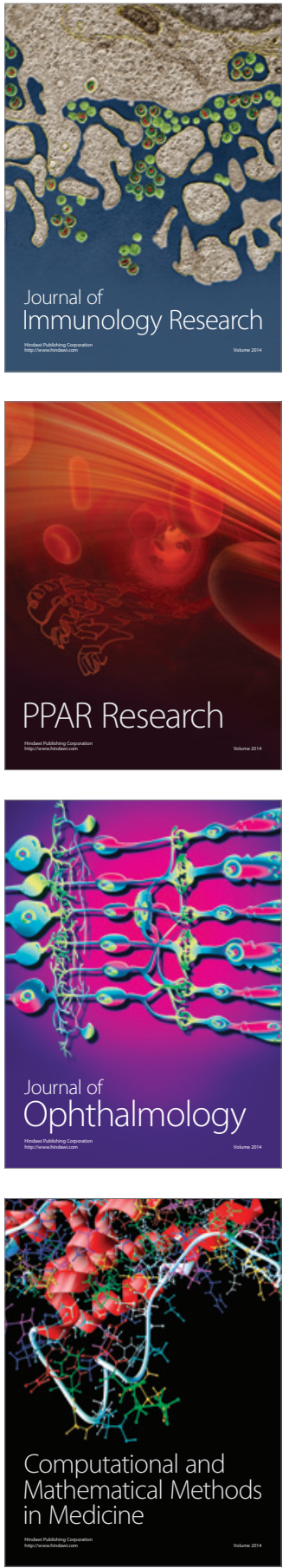

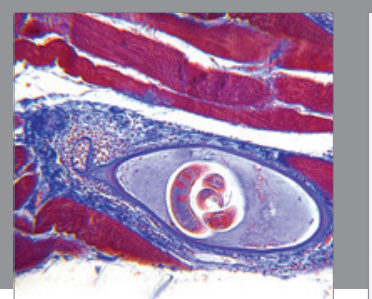

Gastroenterology Research and Practice

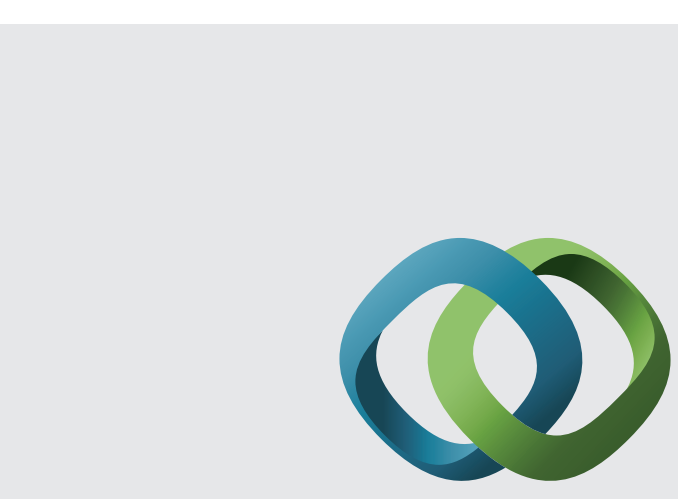

\section{Hindawi}

Submit your manuscripts at

http://www.hindawi.com
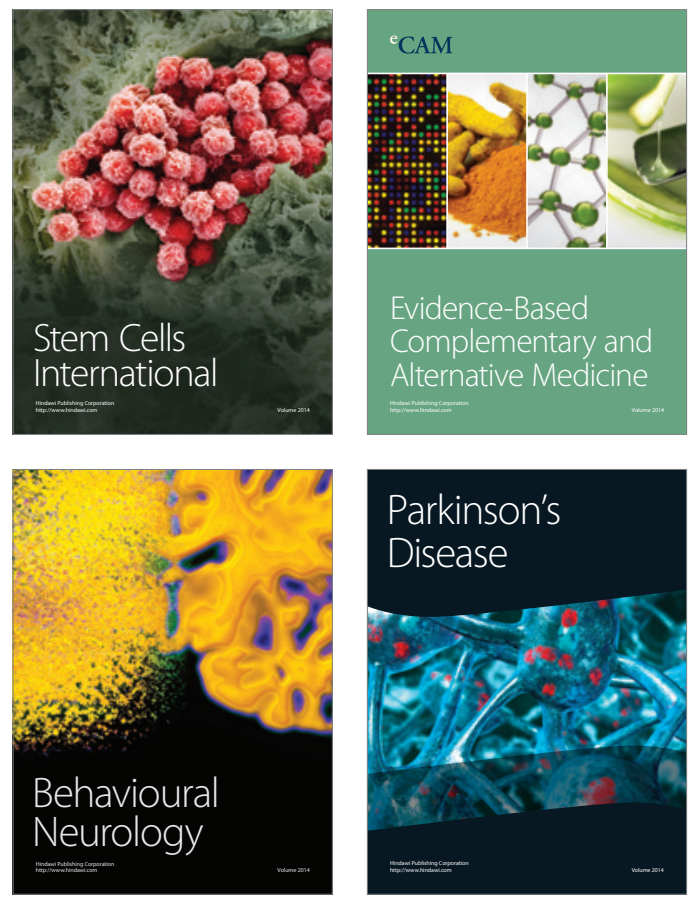
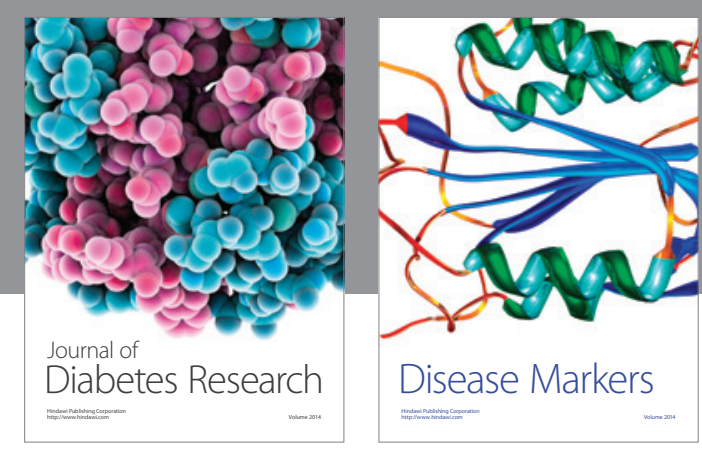

Disease Markers
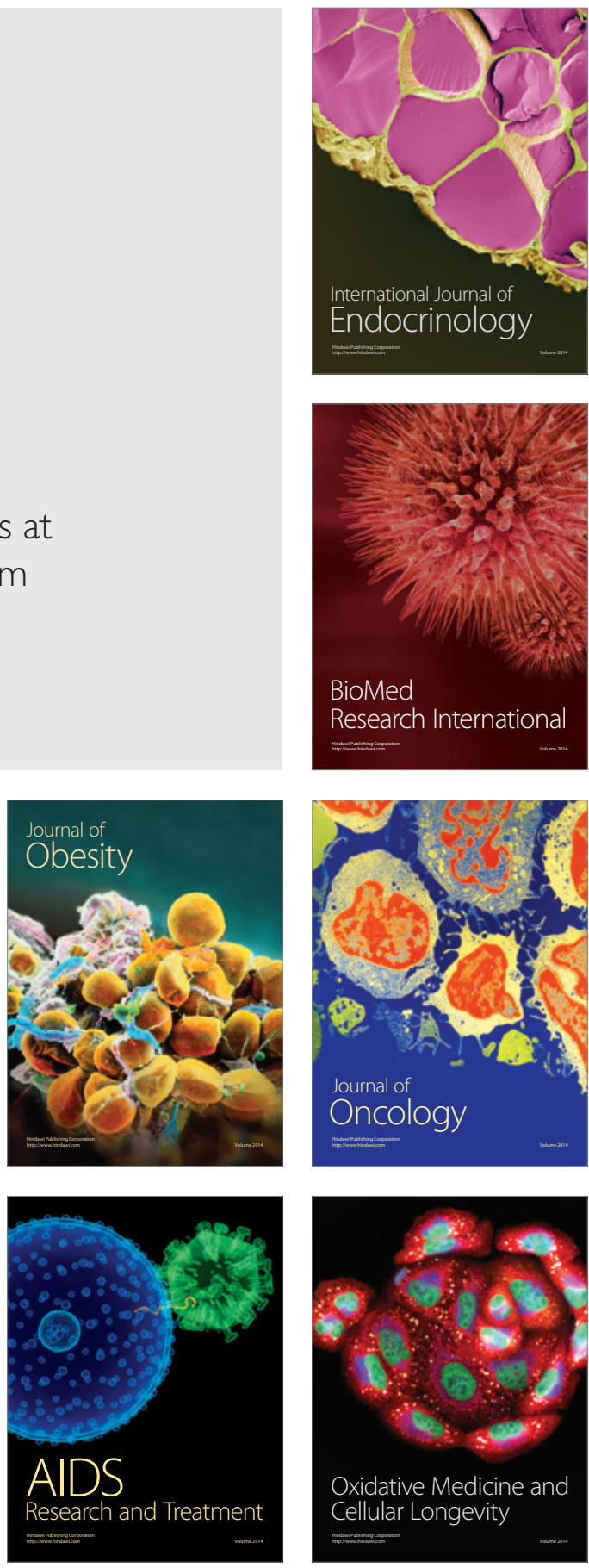